\title{
Production of bacterial cellulose from glycerol: the current state and perspectives
}

\author{
Peteris Zikmanis, Sergejs Kolesovs, Maija Ruklisha and Pavels Semjonovs ${ }^{*}$ (i)
}

\begin{abstract}
Current research in industrial microbiology and biotechnology focuses on the production of biodegradable microbial polymers as an environmentally friendly alternative to the still dominant fossil hydrocarbon-based plastics. Bacterial cellulose (BC) is important among microbial polymers due to its valuable properties and broad applications in variety of fields from medical to industrial technologies. However, the increase in BC production and its wider deployment is still limited by high costs of traditionally used raw materials. It is therefore necessary to focus on less expensive inputs, such as agricultural and industrial by-products or waste including the more extended use of glycerol. It is the environmentally harmful by-product of biofuel production and reducing it will also reduce the risk of environmental pollution. The experimental data obtained so far confirm that glycerol can be used as the renewable carbon source to produce $B C$ through more efficient and environmentally friendly bioprocesses. This review summarizes current knowledge on the use of glycerol for the production of commercially prospective $B C$, including information on producer cultures, fermentation modes and methods used, nutrient medium composition, cultivation conditions, and bioprocess productivity. Data on the use of some related sugar alcohols, such as mannitol, arabitol, xylitol, for the microbial synthesis of cellulose are also considered, as well as the main methods and applications of glycerol pretreatment briefly described.
\end{abstract}

Keywords: Bacterial cellulose, Acetic acid bacteria, Komagataeibacter spp., Glycerol, Sugar alcohols

\section{Introduction}

With the current development of microbial biotechnology, more attention is focused on the expanded use of renewable resources, which is in line with the general concept of a circular economy and means that the waste products of one industry should serve as the raw material for another (Ravindran and Jaiswal 2016; Schilling and Weiss 2021). Such an approach is of particular importance in regard to inexpensive carbon sources for commercially relevant strains of microbes-producers, since the costs of nutrient media largely determine the overall economic efficiency of bioprocesses (Gahlawat and Srivastava 2017; Sperotto et al.2021). For this purpose, numerous by-products, residues and waste of

\footnotetext{
${ }^{*}$ Correspondence: pavels.semjonovs@lu.lv

Laboratory of Industrial Microbiology and Food Biotechnology, Institute of Biology, University of Latvia, 4, Ojara Vaciesa Str., Riga LV-1004, Latvia
}

agricultural, food or biofuel industries are proposed and actually applied (Arancon et al. 2013; Sadh et al. 2018; Tsang et al. 2019; Sperotto et al. 2021), which, in addition to the real economic benefits, also create a very positive impact on the environment. Among them, glycerol, the simplest 3-C polyol, as a sufficiently widely available and relatively cheap compound, is already of significant value and is quite promising in this regard. This is largely due to the fact that the production of biodiesel as well as other products (soap, fatty acid, fatty ester industries) whose technologies involve the triglyceride trans-esterification reaction produces significant amounts of glycerol as a by-product (Kumar et al. 2019). It is also important that many microbial cultures are able to utilize it efficiently for the growth and biosynthesis of high added value compounds (Kenar 2007; da Silva et al. 2009; Wendisch et al. 2011; Trindade et al. 2015). These reasons, as well as the ability of a number of producing strains for 
the use of crude glycerol help to reduce the cost of both the nutrient composition and the end product of microbial synthesis. These products, the biosynthesis of which is based on glycerol as the sole carbon source, represent a fairly wide and versatile set of commercially important compounds such as 1,3-propanediol, ethanol, D-lactic, citric, succinic, propionic acids, glycolipid-type biosurfactants, carotenoids, amino acids and others (Wendisch et al. 2011; Posada et al. 2012; Yang et al. 2012). Thus, among the glycerol-based products of biosynthesis, there are mainly monomers with a relatively simple structure, but the possibilities of obtaining more complex compounds with a high technological potential are reported much less frequently. In particular, it should be noted that the use of renewable sources is especially important for the biosynthesis of microbial polymers, including extracellular polysaccharides, since reducing overall costs is the main precondition for expanding their production and commercial use (Gahlawat and Srivastava 2017; Sperotto et al. 2021). Microbial polymers are an established environmentally friendly alternative to still dominant fossil-based plastics, possess an extensive biotechnological potential and are already widely used in a variety of fields ranging from medicine to technology (Rehm 2010; Narancic and O'Connor 2019; Shanmugam and Abirami 2019; Zikmanis et al. 2020a, b). However, the scope of research, as well as the number of microbial polymers synthesized on glycerol, is more limited than for monomeric compounds, and in addition they are rather unevenly distributed. Thus, the most comprehensive in this regard are studies on the microbial synthesis of polyhydroxyalkanoates (PHA), and in particular polyhydroxybutyrate $(\mathrm{PHB})$ which are the commercially important biodegradable polymers with a wide range of applications. The key issues of conducting and technological implementation for the relevant bioprocesses have been summarized and assessed in a number of reviews, including those in recent years (Licciardello 2017; Adeleye et al. 2020; El-Malek et al. 2020; Sen and Baidurah 2021; Sirohi et al. 2021). Unlike the formation of microbial exopolysaccharides, using glycerol as the sole carbon source still remains less documented. So there are only sporadic reports on the biosynthesis of gellan (Raghunandan et al. 2018) xanthan (Trindade et al. 2015) and some partially identified heteropolysaccharides (Freitas et al. 2011). Bacterial cellulose (BC) is the only commercially important exopolysaccharide (Gorgieva and Trček 2019), whose microbial synthesis on glycerol has been performed for a relatively long time (Masaoka et al. 1993), and therefore a certain amount of data have been accumulated. However, in specialized reviews on bacterial cellulose, such the employment of glycerol is only noted (Cacicedo et al. 2016; Jang et al. 2017; Reiniati et al.
2017; Ul-Islam et al. 2020) or not mentioned at all (Gullo et al. 2018; Salihu et al. 2019; Zhong 2020), and the available data remain not summarized as well as not evaluated in comparison. However, there is a certain desire for this, albeit to a limited extent (Adnan 2015; Hussain et al. 2019; Mangayil et al. 2021). This review summarizes the current knowledge on the use of glycerol to obtain bacterial cellulose, including information about producer cultures, composition of culture media, cultivation conditions and productivity of bioprocesses. The synthesis of BC from some other sugar alcohols (mannitol, arabitol, xylitol) is briefly overviewed. The basic data on the relevant pathways of biosynthesis and their regulation, properties and applications of $\mathrm{BC}$ also are considered.

\section{Basic features and applications of bacterial cellulose}

$\mathrm{BC}$ makes up a significant part among other bacterial exopolysaccharides and represents a polymer of D-glucose, that is, a homopolysaccharide formed mainly by $\beta$ - $(1,4)$ glycosidic bonds from precursors (UDP-D-glucose) (Gorgieva and Trček 2019) through the membraneincorporated glycosyltransferase (cellulose synthase BcsA; EC 2.4.1.29) (Azuma et al. 2009; Lu et al. 2020). Due to their unique three-dimensional network structure, $\mathrm{BC}$ has a combination of exclusive properties such as high crystallinity and degree of polymerization, large surface area, high elasticity, tensile strength and water retention (Wang et al. 2018; Raghavendran et al. 2020; Cazon and Vazquez 2021). BC represents a high-quality and biocompatible material, since it does not contain lignin, hemicellulose, pectin and other biogenic substances, is not cytotoxic and genotoxic. This is particularly important for BC biomedical applications (Ul-Islam et al. 2015; de Oliveira Barud et al. 2016; Moniri et al. 2017; Andriani et al. 2020) in high value-added products (functionalized wound dressings, tissue, heart valves and blood vessels replacement materials, vascular grafts, dental implants, pharmaceutical transfer agents, biosensor elements, etc.). It also appeared to be very promising for use in cosmetics and personal care products (Pacheco et al. 2018; Morais et al. 2019; Bianchet et al. 2020). BC has a multifaceted technological potential (Andriani et al. 2020) and is already used in various industries and production areas, such as textile and paper (Chawla et al. 2009; Pathak and Prasad 2014), mining and refinery (Chawla et al. 2009; Jozala et al. 2016), electronics, energy and communication (Chawla et al. 2009; Baptista et al. 2013; Cacicedo et al. 2016; Li et al. 2019) and waste treatment (Brandes et al. 2018), and especially in food production. BC is used (Shi et al. 2014; Azeredo et al. 2019; Ul-Islam et al. 2020) as an additional thickening, suspending or stabilizing agent to affect the food properties 
in the desired way or used directly for food (traditional dessert, vegetarian meat, food/beverage additives, etc.) as an ingredient in fiber-enriched low-calorie and lowcholesterol diets. It is also very important that the effectiveness of such a variety of applications can be enhanced by targeted modification of the bacterial cellulose properties. This, in turn, can be achieved through a number of different approaches and techniques. Thus, the high hydroxyl content facilitates the formation of multiple $\mathrm{BC}$ derivatives using appropriate chemical (esterification, etherification, amination, oxidation, crosslinking, etc.) reactions (Cook 2013; Reiniati et al. 2017; Gorgieva and Trček 2019) or physical (ultrasonic, rotary magnetic field, UV or $\gamma$-irradiation) treatments (Huang et al. 2014; Campano et al. 2016; Blanco Parte et al. 2020). Extensive possibilities also arise when the features of $\mathrm{BC}$ are modified and improved by using composite materials of two or more ingredients, which leads to their synergistic interaction and enhancement of the resulting properties (Rosa and Lenz 2013). The need for composites is determined by the fact that certain properties of $\mathrm{BC}$ are limited for certain application and must be fine-tuned to match the necessary requirements, particularly for biomedical use (Fu et al. 2013; Feldman 2015). Composites consisting of $\mathrm{BC}$ and other compounds including microbial EPS can be obtained by different processing techniques over a wide range of homogenization conditions up to high pressures and elevated temperatures. However, milder conditions are preferable to avoid any possible destruction (Siro and Plackett 2010; Rosa and Lenz 2013). A relative simple and quite efficient method is an augmentation of $\mathrm{BC}$ by immersion in solutions of various, preferably water-soluble, compounds including microbial EPS. The solutions after mixing with the suspension of cellulosic particles and evaporation or freeze-drying yield composites with a wide range of modified properties (Yasuda et al. 2005; Millon and Wan 2006; Kim et al. 2011). In this case, molecules of soluble compound not only cover the BC fibrils surface, but also penetrate into the fiber network and bind to BC with hydrogen bonds (Fu et al. 2013). As a result, ex situ post-modifications of the $\mathrm{BC}$ to obtain corresponding composites (Klemm et al. 2006) are carried out. Other very promising approach involves the alteration of $\mathrm{BC}$ morphology during its biogenesis. Through this approach bacterial cellulose is modified in situ, i.e., during its biosynthesis, due to the competitive adsorption of a compatible host polymer from the growth medium. Therefore, subsequent to $\mathrm{BC}$ polymerization, the compounds added to the medium associate and co-crystallize with $\mathrm{BC}$, creating the intimately blended composite materials which can offer a wide range of morphological, compositional and functional properties for specific applications (Brown and Laborie 2007; Rosa and Lenz
2013). Importantly the addition of water-soluble polysaccharides to the cultivation medium itself can appear as the BC synthesis stimulating factor (Chao et al. 2001; Ishida et al. 2003). Alike for other microbial polysaccharides, the structure and properties of $\mathrm{BC}$ depend on the cultivation conditions and particular characteristics of the producer culture. Although the ability to synthesize $\mathrm{BC}$ is relatively widespread (the species of Agrobacterium, Aerobacter, Achromobacter, Azotobacter, Rhizobium, Sarcina and others), the most important and industrially employed producer cultures are AAB from the genus Komagataeibacter (formerly known as Gluconacetobacter spp. and Acetobacter spp.), mainly the K.xylinus and K. rheticus strains (Ummartyotin and Sain 2016; Reiniati et al. 2017; Semjonovs et al. 2017a; Gorgieva and Trček 2019; Raghavendran et al. 2020). In addition, producers from different genera and species form BC with elements (pellicles, fibrils, ribbons) of different shapes and sizes (Ummartyotin and Sain 2016). The BC biosynthesis is a rather complex process, which depends on the full composition of the cultivation medium (carbon, nitrogen, micronutrient sources and concentrations), as well as on the culture (temperature, $\mathrm{pH}$, agitation, aeration, growth phase) and operational (bioreactor type and mode of operation) (Mohite et al. 2017; Ul-Islam et al. 2017; Wang et al. 2018; Barcelos et al. 2019; Raghavendran et al. 2020; Tiwari et al. 2020). In general, the bioprocess is also complicated by the strong evidence that the yield and physico-chemical characteristics of produced BC not only depend on the aforementioned factors, but also the magnitude and direction of their complex effects are highly strain-dependent. This, in turn, creates the need to find and define the most appropriate cultivation conditions for each individual producer strain (Olivas and BarbosCanovas 2005; Nwodo et al. 2012; Devi and Alamu 2013; Semjonovs et al. 2017b), even if the same microbial species synthesizes the same EPS. However, a number of generalized features and conditions promoting

\section{Sugar alcohols as nutrients for acetic acid bacteria}

$\mathrm{AAB}$ are characterized by their ability to oxidize not only carbohydrates and alcohols, including glycerol, but also sugar alcohols (polyhydric alcohols or polyols) into organic acids, aldehydes or ketones to gain energy in a process termed "oxidative fermentation", with some of the genera forming BC (Taban and Saichana 2017; La China et al. 2018; Lynch et al. 2019). The most important of these are the 6-carbon (6-C) mannitol and the 5-C stereoisomers arabitol, xylitol and ribitol. In this respect, mannitol has long been used relatively more frequently and successfully (Minor et al. 1954), when the formation of C14-labeled BC from D-mannitol-1-C14 by A. xylinum $s p$. was confirmed. The productivity of $\mathrm{BC}$ formation 
from mannitol varies over a fairly wide range and depends on the specific characteristics of the producing culture, in many cases exceeding the levels achieved on mostly used carbon sources (glucose or fructose). Thus, when cultivated under static conditions with $1.5 \%$ mannitol as the sole carbon source, A. xylinum KU-1 achieved relatively high $\mathrm{BC}$ concentration and specific productivity of $4.6 \mathrm{~g} / \mathrm{L}$ and $0.027 \mathrm{~g} / \mathrm{L} / \mathrm{h}$, respectively. Under the same conditions, these indices were significantly lower $(1.2 \mathrm{~g} / \mathrm{L}$ and $0.007 \mathrm{~g} / \mathrm{L} / \mathrm{h}$ ) for $1.5 \%$ glucose (Oikawa et al. 1995a). In addition, no gluconic acid accumulates in the mannitol medium, thus maintaining a $\mathrm{pH}$ value about 6.0 favorable for BC synthesis, while unwanted acidification ( $\mathrm{pH}$ 3.4) is observed on the glucose (Oikawa et al. 1995a). Moreover in another study with $A$. xylinum $s p$. it was shown that the use of mannitol $(50 \mathrm{~g} / \mathrm{L})$ in a longer-time cultivation under static conditions makes it possible to achieve a relatively high $\mathrm{BC}$ yield (about $4.75 \mathrm{~g} / \mathrm{L}$ ), but with lower specific productivity $(0.014 \mathrm{~g} / \mathrm{L} / \mathrm{h})$, which still exceeds the values for glucose as the carbon source, but are commensurate with or slightly below the indices for sucrose medium also depending on the nitrogen sources used (Ramana et al. 2000). In addition, when growing Gluconacetobacter hansenii ATCC 10821 on $2 \%$ mannitol the $\mathrm{BC}$ yield and productivity were $20-25 \%$ above that in the glucose medium but remained rather low $(1.13 \pm 014 \mathrm{~g} / \mathrm{L}$; $0.0021 \mathrm{~g} / \mathrm{L} / \mathrm{h})$ under selected $\left(20^{\circ} \mathrm{C}\right.$; pH 5.5) static culture conditions (Hutchens et al. 2007). Similar data on the use of mannitol for $\mathrm{BC}$ synthesis with a higher productivity as compared to glucose, fructose or sucrose were also obtained with other producer cultures such as G. xylinus ATCC10245 (El-Saied et al. 2008), G. xylinus K3 (Nguen et al. 2008), wild-type isolates G. xylinus sp. S and G. xylinus sp. A2 (Jalili Tabaii and Emtiazi 2016), Gluconacetobacter $s p$. isolate PAP1 (Suwanposri et al. 2013), as well as G. xylinus ATCC 53524 (Mikkelsen et al. 2009), but in this case only for short (48 h) cultivation and later $(96 \mathrm{~h}$ ) slightly lagging behind the productivity of sucrose. A somewhat higher BC yield and specific productivity $(3.9 \mathrm{~g} / \mathrm{L} ; 0.163 \mathrm{~g} / \mathrm{L} / \mathrm{h})$ in the 24 -h cultivation in shaking flasks $(140 \mathrm{rpm})$ on mannitol as compared to glucose $(3.2 \mathrm{~g} / \mathrm{L} ; 0.133 \mathrm{~g} / \mathrm{L} / \mathrm{h})$ were also confirmed for the producer strain A. aceti MTCC2623 (Dayal et al. 2013). However, differing effects of mannitol on BC yield and productivity have also been reported (Son et al. 2001; Jung et al. 2010). Thus, when Acetobacter sp. A9 was used as a producer (Son et al. 2001), the yield of BC on $2 \%$ mannitol $(0.64 \mathrm{~g} / \mathrm{L})$ proved to be substantially below that for glucose $(2.70 \mathrm{~g} / \mathrm{L})$, fructose $(2.53 \mathrm{~g} / \mathrm{L})$ and sucrose $(0.83 \mathrm{~g} / \mathrm{L})$, as well as specific productivity $(0.013 \mathrm{~g} / \mathrm{L} / \mathrm{h}$, $0.056 \mathrm{~g} / \mathrm{L} / \mathrm{h}, 0.053 \mathrm{~g} / \mathrm{L} / \mathrm{h}$ and $0.017 \mathrm{~g} / \mathrm{L} / \mathrm{h}$, respectively). Similar characteristics were also observed for Acetobacter sp. V6 (Jung et al. 2010) when only $0.45 \mathrm{~g} / \mathrm{L} \mathrm{BC}$ was obtained in the 7-day cultivation on mannitol, significantly lagging behind glucose $(1.13 \mathrm{~g} / \mathrm{L})$, although well above the yield for sucrose $(0.14 \mathrm{~g} / \mathrm{L})$. Substantially higher yields of $\mathrm{BC}$ from glucose, fructose, and sucrose compared to mannitol were observed using the producer strain G. xylinus PTTC 1734 (Jalili Tabaii and Emtiazi 2016), as well as from fructose in the case of Komagataeibacter sp.W1 (Wang et al. 2018) or from glucose using G. sacchari $s p$. isolated from Kombucha tea (Trovatti et al. 2011). Some recent studies on the use of mannitol in the production of $\mathrm{BC}$ have shown fairly good yield and productivity characteristics using the producers $K$. xylinus SB3.1 (Alemam et al. 2021) and K. xylinus K2G30 (UMCC 2756) (Gullo et al. 2019). Their levels, especially in the case of K2G30 (8.77 g/L; $0.041 \mathrm{~g} / \mathrm{L} / \mathrm{h})$, indicate some potential for the industrial scale-up of $\mathrm{BC}$ production using vegetable waste feedstocks rich in mannitol and other sugar alcohols (Gullo et al. 2019). In addition, during cultivation these carbon sources prevent the formation of gluconic acid, which decrease the $\mathrm{pH}$ far below the optimum value for $\mathrm{BC}$ production (Oikawa et al. 1995a; Gullo et al. 2019). Compared to mannitol, other sugar alcohols, such as arabitol and xylitol were used much less frequently as carbon sources for BC synthesis, and the yields and productivity obtained were rather low or moderate (Son et al. 2001; Singhsa et al. 2018; Gullo et al. 2019).

The fact that generally the yield and productivity of $\mathrm{BC}$ on arabitol and xylitol remain below that on mannitol is due to the differences in respective metabolic pathways. Thus, a soluble and highly substrate-specific D-mannitol dehydrogenase (Oikawa et al. 1997) realizes a direct enzymatic conversion of mannitol to fructose, which is subsequently phosphorylated to fructose-6-P to be involved in the further metabolic pathway to BC (Fig. 1). Contrary to D-mannitol, the production of $\mathrm{BC}$ from arabitol or xylitol is a more complex pathway, involving additional steps, such as the intermediate formation and phosphorylation of xylulose, followed by conversion to glyceraldehyde-3-P to enter the main stream (Fig. 1) of biosynthesis (Bettiga et al. 2008; Laslo et al. 2012; Glenn et al. 2014), whose result is less advantageous energetically for the cell (Gullo et al. 2019). Although using the producer A. xylinum KU-1, a very high BC yield and productivity $(12.4 \mathrm{~g} / \mathrm{L} ; 0.129 \mathrm{~g} / \mathrm{L} / \mathrm{h})$ were achieved on arabitol, which is higher than that for mannitol, and even six times more $(2.0 \mathrm{~g} / \mathrm{L} ; 0.021 \mathrm{~g} / \mathrm{L} / \mathrm{h})$ than for glucose (Oikawa et al. 1995a, b; Oikawa et al. 1997), also suggesting the possibility of activation for this pathway under certain conditions and, consequently, the full use of 5-C sugar alcohols from vegetable raw materials (Laslo et al. 2012; Gullo et al. 2019). 


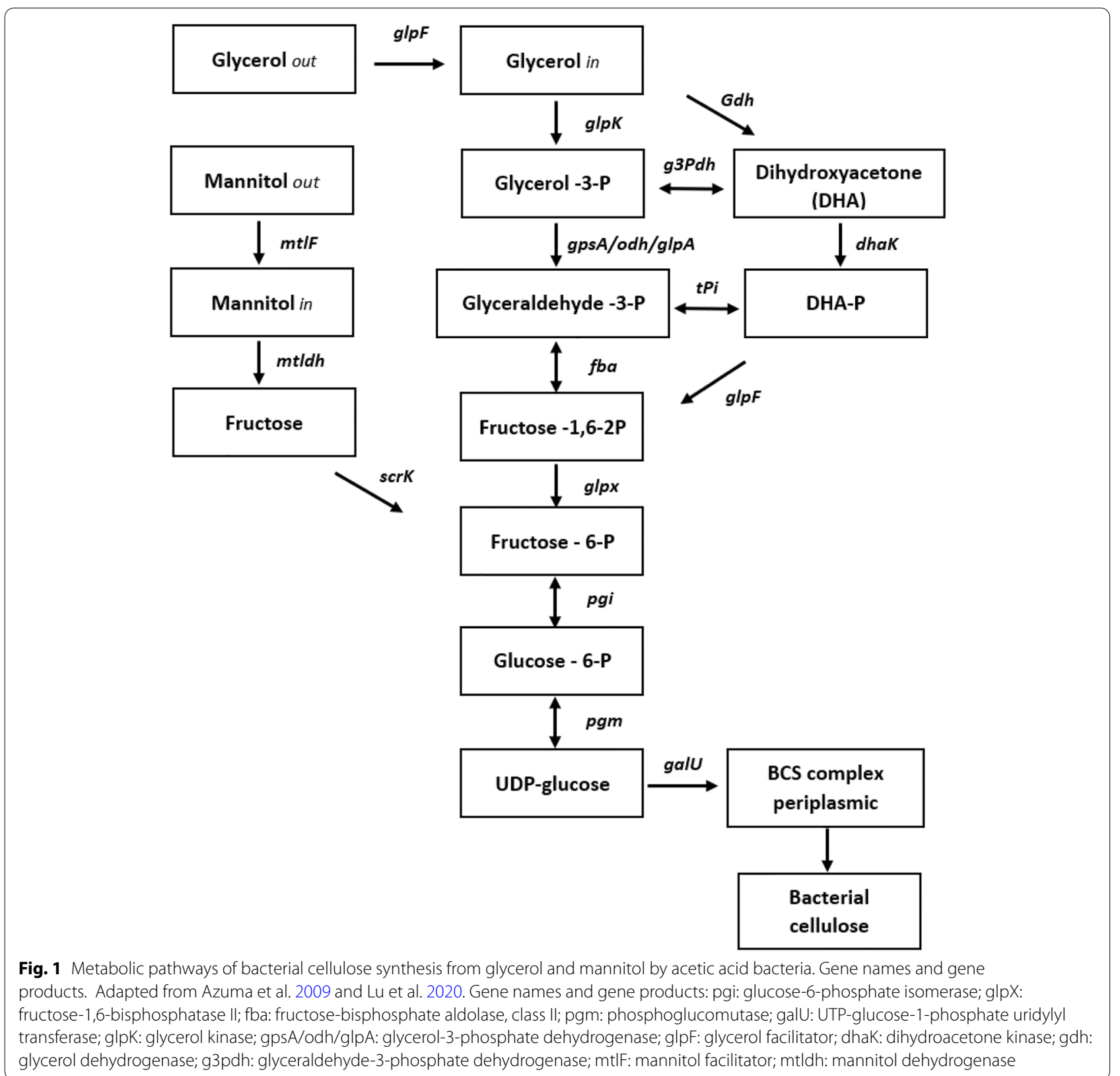

\section{Glycerol as an appropriate feedstock for the synthesis of bacterial cellulose}

However, despite such manifestations of individual polyols, it is glycerol that has a clear advantage for the use as a raw material in the production of bacterial cellulose. Thus, in view of the large volume of glycerol that accompanies the ever-increasing production of diesel fuel from renewable fats and oils (da Silva et al. 2009; Wendisch et al. 2011; Trindade et al. 2015), almost all restrictions on the availability and prices of carbon sources for BC biosynthesis have been removed (Vazquez et al. 2013). In addition, glycerol easily enters the metabolic network of producing cells (da Silva et al. 2009), by facilitated diffusion (Fig. 1), while other also renewable and cost-efficient feedstocks, such as molasses or cheese whey, require for this an enzymatic or chemical hydrolysis of relevant disaccharides (sucrose and lactose, respectively). This need is due to the fact that, for example, the activity of $\beta$-galactosidase in AAB is often too small for efficient hydrolysis of lactose to obtain glucose for BC synthesis (Lappa et al. 2019; Zikmanis et al. 2020a, b). In turn, sucrose cannot be transported across the cell membrane 
and is hydrolyzed in the periplasm to glucose and fructose by $\alpha$-glucosidase, which has very varied and often insufficient activities for different producer strains (VelascoBedrán and López-Isunza 2007; Mikkelsen et al. 2009; Jalili Tabaii and Emtiazi 2016; Raghavendran et al. 2020). Therefore, these substrates should be subjected to preliminary hydrolytic treatment using appropriate enzymes or less expensive chemical hydrolysis with mineral acids (Marangoni et al. 2002; Bae and Shoda 2004; Torres et al. 2010; Kucera et al. 2018). The efficiency of using glycerol is also determined by the fact that the necessary enzymatic stages of its catabolism are well-represented in the metabolic network of $\mathrm{BC}$ producers (Azuma et al. 2009; Lu et al. 2020). For this, alternative ways are possible (Fig. 1), such as inclusion in the biosynthesis chain at the level of glyceraldehyde-3-P after phosphorylation of glycerol with glycerol kinase (glpK) and subsequent transformation by glycerol-3-P dehydrogenase (gpsA/ odh/glpA) or through the intermediate formation of dihydroacetone (DHA) by glycerol dehydrogenase (Gdh) phosphorylation to DHA-P with dihydroacetone kinase (dhaK) and isomerization by triose-P-isomerase (tPi), DHA-P can also enter at the fructose-1.6-2P level (Fig. 1) after transformation by fructose-biphosphate aldolase (fba). Further enzymatic transformations, as for all other substrates, pass through the formation of glucose6-phosphate, which is converted to glucose-1-phosphate and subsequently metabolized to uridine diphosphoglucose (UDP-glucose), a direct precursor of BC. UDP biosynthesis is controlled by phosphoglucomutase (pgm) and UTPG-1-P uridylyl transferase (galU) also referred as UDPG pyrophosphorylase (Thoden and Holden 2007; Lynch et al. 2019). After the formation of UDP-glucose, the polymerization of glucose into $\mathrm{BC}$ is mediated by cellulose synthase (CS), a complex of proteins spanning the periplasmic space between the bacterial cytoplasmic and outer membranes. The CS complex promotes UDPglucose polymerization, polymer translocation across bacterial membranes, and extracellular assembly of glucan chains (Tonouchi 2016; Lynch et al. 2019). The activities and structure of CS in detail have been discussed in several reviews (Adnan 2015; McNamara et al. 2015; Jang et al. 2017; Gullo et al. 2018; Raghavendran et al. 2020). It is important to note that the CS complex is encoded by a four-gene (bcsA, bcsB, bcsC, and bcsD) operon which determines the formation and activity of the corresponding elements, including the catalytic (AcsA) and regulatory $(\mathrm{B} \operatorname{csB})$ subunits. In turn, their activity and, therefore, the entire complex is under allosteric regulatory control by means of the cyclic diguanosine monophosphate (c-di-GMP), the binding of which to the BcsB regulatory subunit activates the AcsA catalytic subunit via its $C$-terminal transmembrane helix (Lu et al. 2020; Buldum et al.
2018; Römling and Galperin 2015). The degree of activation depends on the level of cellular c-di-GMP, which is determined by several external and internal factors such as oxygen availability, intracellular potassium concentration, diguanylate cyclase and phosphodiesterase activities (Gullo et al. 2018; Raghavendran et al. 2020) Assessing the above problems as a whole, it becomes quite clear why the studies on the use of glycerol for the production of $\mathrm{BC}$, although not very numerous, significantly exceed the current volume of relevant studies using molasses (Adnan 2015; Campano et al. 2016; Zhong 2020) or cheese whey (Kolesovs and Semjonovs 2020; Zikmanis et al. 2020a, b). The main results on the use of glycerol for $\mathrm{BC}$ synthesis are summarized in Table 1.

Producer cultures, whose ability to synthesize bacterial cellulose from glycerol have been documented, represent exclusively acetic acid bacteria (Table 1) of the genus Komagataeibacter (formerly Acetobacter, Gluconacetobacter) with only one exception for conditionally pathogenic Enterobacter amnigenus (Hungund and Gupta 2010b). Although these studies were mainly performed with organisms of the same species (K.xylinus or $K$. rhaeticus), in all cases different strains of producers were used, both from representative collections (ATCC, DSMZ, NRRL, etc.) of microorganisms and from relatively less characterized isolates of different origins. This characterizes both the widespread ability of AAB to biosynthesize $\mathrm{BC}$ from glycerol and makes it difficult to compare the data to select the most promising producer based on its productivity. It can be seen (Table 1) that relevant indicators such as the yield and specific productivity vary over a very wide range, from the relatively insignificant (Carreira et al. 2011; Lins et al. 2019) to quite high levels, confirming the biotechnological potential of such producers (Vazquez et al. 2013; Volova et al. 2018; Soemphol et al. 2018; Vigentini et al. 2019). These data are in line with the oft-confirmed finding that microbial synthesis of extracellular polysaccharides is highly strain-dependent (Olivas and Barbos-Canovas 2005; Nwodo et al. 2012; Devi and Alamu 2013; Semjonovs et al. 2017b), including the formation of $\mathrm{BC}$ from glycerol, and thus suggest that further in-depth comparative studies of relevant genotypic and phenotypic traits of potential producers are urgently needed. This is especially evident in the fact that bacterial sub-clones with persistent phenotypic properties and markedly different productivity of $\mathrm{BC}$ synthesis can be isolated even from a supposedly homogeneous producer strain, such as K. rhaeticus LMG 22126 (Vigentini et al. 2019). Besides, the composition of the cultivation medium and the chosen operational conditions also are very important to promote the BC biosynthesis. Producer cultures were predominantly cultivated in a standard (Mikkelsen et al. 2009; Tsouko et al. 2015; Thorat and 
Table 1 Production of bacterial cellulose by acetic acid bacteria from pure or crude glycerol as the sole carbon source

\begin{tabular}{|c|c|c|c|c|c|}
\hline Bacterial strain & Growth medium & Cultivation mode & Medium composition & Production metrics ${ }^{\mathrm{a}}$ & References \\
\hline $\begin{array}{l}\text { Komagataeibacter } \\
\text { sucrofermentans } \\
\text { DSM15973 }\end{array}$ & $\mathrm{HS}$ & Static & $\begin{array}{l}20 \mathrm{~g} / \mathrm{L} \mathrm{pGLYYC} \text { or } 20 \mathrm{~g} / \mathrm{L} \\
\mathrm{cGLYC}, 5 \mathrm{~g} / \mathrm{L} \mathrm{YE}, 5 \mathrm{~g} / \mathrm{L} \\
\text { Pep, } 1.1 \mathrm{~g} / \mathrm{L} \text { citric acid }\end{array}$ & $\begin{array}{l}\text { pGLYC } 1.9 \mathrm{~g} / \mathrm{L} \\
(0.008 \mathrm{~g} / \mathrm{L} / \mathrm{h}) \\
\text { CGLYC } 6.4 \mathrm{~g} / \mathrm{L} \\
(0.027 \mathrm{~g} / \mathrm{L} / \mathrm{h})\end{array}$ & Lee et.al. (2021) \\
\hline K. hansenii ATCC 53582 & $\mathrm{HS}$ & Static & $\begin{array}{l}\text { 2\% pGLYC, } 0.5 \% \text { YE, } \\
0.5 \% \text { Pep }\end{array}$ & $4.93 \mathrm{~g} / \mathrm{L}(0.068 \mathrm{~g} / \mathrm{L} / \mathrm{h})$ & Li et al. (2021) \\
\hline K. rhaeticus ENS9a & $\mathrm{MA} / 9$ & Static & $\begin{array}{l}20 \mathrm{~g} / \mathrm{L} \mathrm{pGLYC} \\
20 \mathrm{~g} / \mathrm{L} \mathrm{cGLYC}\end{array}$ & $\begin{array}{l}2.6 \mathrm{~g} / \mathrm{L}(0.01 \mathrm{~g} / \mathrm{L} / \mathrm{h}) \\
2.9 \mathrm{~g} / \mathrm{L}(0.01 \mathrm{~g} / \mathrm{L} / \mathrm{h})\end{array}$ & Mangayil et al. (2021) \\
\hline A.senegalensis MA1 & $\mathrm{HS}$ & Static & $\begin{array}{l}63 \mathrm{~g} / \mathrm{L} \mathrm{pGLYC}, 7.5 \mathrm{~g} / \mathrm{L} \\
\mathrm{YE} ; 7.76 \mathrm{~g} / \mathrm{L} \text { PEG } 6000\end{array}$ & $\begin{array}{l}469.83 \mathrm{~g} / \mathrm{L}(0.652 \mathrm{~g} / \mathrm{L} / \\
\mathrm{h})^{\mathbf{b}}\end{array}$ & Aswini et al. (2020) \\
\hline G.xylinus sp. & $\mathrm{HS}$ & Static & $\begin{array}{l}20 \mathrm{~g} / \mathrm{L} \text { cGLYC, } 5 \text { g/L YE, } \\
5 \mathrm{~g} / \mathrm{L} \text { Pep } \\
40 \mathrm{~g} / \mathrm{L} \mathrm{cGLYC}, 5 \mathrm{~g} / \mathrm{L} \mathrm{YE}, \\
5 \mathrm{~g} / \mathrm{L} \mathrm{Pep}\end{array}$ & $\begin{array}{l}1.5 \mathrm{~g} / \mathrm{L}(0.01 \mathrm{~g} / \mathrm{L} / \mathrm{h}) \\
2.9 \mathrm{~g} / \mathrm{L}(0.02 \mathrm{~g} / \mathrm{L} / \mathrm{h})\end{array}$ & Dikshit and Kim (2020) \\
\hline $\begin{array}{l}\text { Komagataeibacter } \\
\text { sp.nov } \\
\text { CGMCC 17,276 }\end{array}$ & $\mathrm{AE}$ & Static & 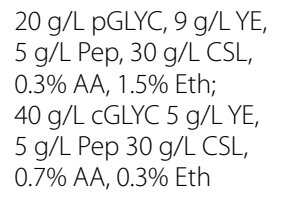 & $\begin{array}{l}4.5 \mathrm{~g} / \mathrm{L}(0.05 \mathrm{~g} / \mathrm{L} / \mathrm{h}) \\
6 \mathrm{~g} / \mathrm{L}(0.06 \mathrm{~g} / \mathrm{L} / \mathrm{h})\end{array}$ & Lu et al. (2020) \\
\hline K. hansenii JR-02 & $\begin{array}{l}\text { HS } \\
\text { modified }\end{array}$ & Static & $\begin{array}{l}20 \mathrm{~g} / \mathrm{L} \mathrm{pGLYC}, 2.5 \mathrm{~g} / \mathrm{L} \\
\mathrm{YE}, 2.5 \mathrm{~g} / \mathrm{L} \mathrm{Pep}\end{array}$ & $2.4 \mathrm{~g} / \mathrm{L}(0.01 \mathrm{~g} / \mathrm{L} / \mathrm{h})$ & Li et al. (2019) \\
\hline G. xylinus ATCC 23769 & $\mathrm{HS}$ & Static & $\begin{array}{l}30 \mathrm{~g} / \mathrm{L} \mathrm{cGLYC}, 16 \mathrm{~g} / \mathrm{L} \mathrm{YE} \\
4 \mathrm{~g} / \mathrm{L} \mathrm{Na}_{2} \mathrm{HPO}_{4}, 3.5 \mathrm{~g} / \mathrm{L} \\
\text { succinic acid }\end{array}$ & $0.24 \mathrm{~g} / \mathrm{L}(1.4 \mathrm{mg} / \mathrm{L} / \mathrm{h})$ & Lins et al. (2019) \\
\hline A. xylinum sp. & $\mathrm{HS}$ & Static & $\begin{array}{l}40 \mathrm{~g} / \mathrm{L} \text { cGLYC, } 5 \mathrm{~g} / \mathrm{L} Y \mathrm{E} \\
5 \mathrm{~g} / \mathrm{L} \mathrm{Pep}\end{array}$ & $1.5 \mathrm{~g} / \mathrm{L}(4 \mathrm{mg} / \mathrm{L} / \mathrm{h})$ & Wu et al. (2019) \\
\hline G. xylinus KCCM 41431 & $\mathrm{HS}$ & Static & 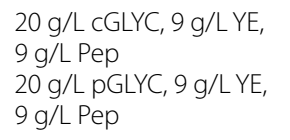 & $\begin{array}{l}7.4 \mathrm{~g} / \mathrm{L}(0.041 \mathrm{~g} / \mathrm{L} / \mathrm{h}) \\
7.7 \mathrm{~g} / \mathrm{L}(0.044 \mathrm{~g} / \mathrm{L} / \mathrm{h})\end{array}$ & Yang et al. (2019) \\
\hline $\begin{array}{l}\text { Komagataeibacter sac- } \\
\text { charivorans sp. }\end{array}$ & $\mathrm{HS}$ & Static & $\begin{array}{l}20 \mathrm{~g} / \mathrm{L} \text { cGLYC, } 5 \text { g/L YE, } \\
5 \mathrm{~g} / \mathrm{L} \mathrm{Pep}\end{array}$ & $12.6 \mathrm{~g} / \mathrm{L}(0.08 \mathrm{~g} / \mathrm{L} / \mathrm{h})$ & $\begin{array}{l}\text { Gayathri and Srinikethan } \\
\text { (2018) }\end{array}$ \\
\hline G.xylinus BNKC19 & $\mathrm{HS}$ & Static & $\begin{array}{l}10 \mathrm{~g} / \mathrm{L} \mathrm{cGLYC}, 5 \mathrm{~g} / \mathrm{L} \mathrm{YE} \\
5 \mathrm{~g} / \mathrm{L} \text { Pep }\end{array}$ & $12.3 \mathrm{~g} / \mathrm{L}(0.07 \mathrm{~g} / \mathrm{L} / \mathrm{h})$ & Soemphol et al. (2018) \\
\hline K. rhaeticus PG2 & $\mathrm{HS}$ & Static & $\begin{array}{l}20 \mathrm{~g} / \mathrm{L} \text { pGLYC, } 5 \mathrm{~g} / \mathrm{L} Y E_{1} \\
5 \mathrm{~g} / \mathrm{L} \text { Pep } \\
30 \mathrm{~g} / \mathrm{L} \mathrm{pGLYC}, 5 \mathrm{~g} / \mathrm{L} Y E_{1} \\
5 \mathrm{~g} / \mathrm{L} \text { Pep }\end{array}$ & $\begin{array}{l}6.9 \mathrm{~g} / \mathrm{L}(0.02 \mathrm{~g} / \mathrm{L} / \mathrm{h}) \\
8.7 \mathrm{~g} / \mathrm{L}(0.02 \mathrm{~g} / \mathrm{L} / \mathrm{h}\end{array}$ & $\begin{array}{l}\text { Thorat and Dastager } \\
\text { (2018) }\end{array}$ \\
\hline K. xylinus B-12068 & $\begin{array}{l}\text { HS } \\
\text { modified }\end{array}$ & Static & $\begin{array}{l}20 \mathrm{~g} / \mathrm{L} \mathrm{pGLYC}, 5 \mathrm{~g} / \mathrm{L} \mathrm{YE} \\
5 \mathrm{~g} / \mathrm{L} \text { Pep, 3\% Eth }\end{array}$ & $23.2 \mathrm{~g} / \mathrm{L}(0.14 \mathrm{~g} / \mathrm{L} / \mathrm{h})$ & Volova et al. (2018) \\
\hline $\begin{array}{l}\text { Komagataeibacter sp. } \\
\text { W1 }\end{array}$ & $\mathrm{HS}$ & Static & $\begin{array}{l}20 \mathrm{~g} / \mathrm{L} \mathrm{pGLYC,} 5 \mathrm{~g} / \mathrm{L} \mathrm{YE} \\
5 \mathrm{~g} / \mathrm{L} \mathrm{Pep}\end{array}$ & $1.2 \mathrm{~g} / \mathrm{L}(4 \mathrm{mg} / \mathrm{L} / \mathrm{h})$ & Wang et al. (2018) \\
\hline $\begin{array}{l}\text { Gluconoacetobacter } \\
\text { xylinus DSM46604 }\end{array}$ & Defined, YE containing & $\begin{array}{l}\text { Shake flasks } \\
\text { agitated } \\
\text { Bioreactor 3L, } \\
\text { agitated/aerated }\end{array}$ & $\begin{array}{l}20 \mathrm{~g} / \mathrm{L} \mathrm{pGLYC,} 5 \mathrm{~g} / \mathrm{L} \mathrm{YE} \\
5 \mathrm{~g} / \mathrm{L}\left(\mathrm{NH}_{4}\right)_{2} \mathrm{SO}_{4} \\
3 \mathrm{~g} / \mathrm{L} \mathrm{K}_{2} \mathrm{HPO}_{4}, 0.05 \mathrm{~g} / \mathrm{L} \\
\mathrm{MgSO}_{4}\end{array}$ & $\begin{array}{l}1.43 \mathrm{~g} / \mathrm{L}(0.012 \mathrm{~g} / \mathrm{L} / \mathrm{h}) \\
2.87 \mathrm{~g} / \mathrm{L}(0.024 \mathrm{~g} / \mathrm{L} / \mathrm{h})\end{array}$ & $\begin{array}{l}\text { Adnan et al. (2015) } \\
\text { Adnan (2015) }\end{array}$ \\
\hline $\begin{array}{l}\text { Gluconoacetobacter } \\
\text { sp. A2 }\end{array}$ & $\mathrm{HS}$ & Static & $\begin{array}{l}20 \mathrm{~g} / \mathrm{L} \mathrm{pGLYC,5} \mathrm{g} / \mathrm{LYE} \\
5 \mathrm{~g} / \mathrm{L} \mathrm{Pep}\end{array}$ & $1.95 \mathrm{~g} / \mathrm{L}(0.027 \mathrm{~g} / \mathrm{L} / \mathrm{h})$ & $\begin{array}{l}\text { Jalili Tabaii and Emtiazi } \\
\text { (2016) }\end{array}$ \\
\hline $\begin{array}{l}\text { K. sucrofermentans DSM } \\
15,973\end{array}$ & $\mathrm{HS}$ & Static & $\begin{array}{l}20 \mathrm{~g} / \mathrm{L} \mathrm{cGLYC,5} \mathrm{g} / \mathrm{L} \text { YE, } \\
5 \mathrm{~g} / \mathrm{L} \text { Pep }\end{array}$ & $3.2 \mathrm{~g} / \mathrm{L}(0.01 \mathrm{~g} / \mathrm{L} / \mathrm{h})$ & Tsouko et al. (2015) \\
\hline Acetobacter xylinum $\mathrm{AJ}_{3}$ & $\begin{array}{l}\text { Defined,YE,peptone } \\
\text { containing }\end{array}$ & Static & $\begin{array}{l}35 \mathrm{~g} / \mathrm{L} \mathrm{pGLYC}, 10 \mathrm{~g} / \mathrm{L} \\
\mathrm{YE}, 7.5 \mathrm{~g} / \mathrm{L} \mathrm{Pep}, 10 \mathrm{~g} / \mathrm{L} \\
\mathrm{Na}_{2} \mathrm{HPO}_{4}, 10 \mathrm{~g} / \mathrm{L} \mathrm{AA}\end{array}$ & $8.52 \mathrm{~g} / \mathrm{L}(0.044 \mathrm{~g} / \mathrm{L} / \mathrm{h})$ & $\begin{array}{l}\text { Al-Shamary and Al- } \\
\text { Darwash (2013) }\end{array}$ \\
\hline A. xylinum DSMZ-2004 & $\begin{array}{l}\text { Semidefined, YE, apple } \\
\text { extract containing }\end{array}$ & Static & $\begin{array}{l}2 \% \text { pGLYC, } 2.5 \% \text { glu- } \\
\text { cose (apples), } 0.05 \% \text { YE, } \\
0.3 \%\left(\mathrm{NH}_{4}\right)_{2} \mathrm{SO}_{4}, 0.5 \% \\
\text { citric acid }\end{array}$ & $8.6 \mathrm{~g} / \mathrm{L}(0.026 \mathrm{~g} / \mathrm{L} / \mathrm{h}$ & Casarica et al. (2013) \\
\hline
\end{tabular}


Table 1 (continued)

\begin{tabular}{|c|c|c|c|c|c|}
\hline Bacterial strain & Growth medium & Cultivation mode & Medium composition & Production metrics $^{a}$ & References \\
\hline G. intermedius NEDO-01 & $\mathrm{HS}$ & $\begin{array}{l}\text { Shake flasks rotating } \\
\text { Bioreactor } 5 \mathrm{~L}, \\
\text { agitated/aerated }\end{array}$ & $\begin{array}{l}20 \mathrm{~g} / \mathrm{L} \mathrm{cGLYC,5} \mathrm{g} / \mathrm{L} \mathrm{YE} \\
5 \mathrm{~g} / \mathrm{L} \text { Pep, } 25 \mathrm{~g} / \mathrm{L} \mathrm{CMC}\end{array}$ & $\begin{array}{l}1.3 \mathrm{~g} / \mathrm{L}(0.01 \mathrm{~g} / \mathrm{L} / \mathrm{h}) \\
3.4 \mathrm{~g} / \mathrm{L}(0.034 \mathrm{~g} / \mathrm{L} / \mathrm{h})\end{array}$ & Kose et al. (2013) \\
\hline $\begin{array}{l}\text { G. sucrofermentans } \\
\text { CECT } 7291\end{array}$ & $\mathrm{HS}$ & Static & $\begin{array}{l}20 \mathrm{~g} / \mathrm{L} \mathrm{pGLYC}, 5 \mathrm{~g} / \mathrm{L} \\
Y E, 5 \mathrm{~g} / \mathrm{L} \text { Pep, } 2.7 \mathrm{~g} / \mathrm{L} \\
\mathrm{Na}_{2} \mathrm{HPO}_{4}, 1.15 \mathrm{~g} / \mathrm{L} \text { citric } \\
\text { acid }\end{array}$ & $2.0 \mathrm{~g} / \mathrm{L}(0.0064 \mathrm{~g} / \mathrm{L} / \mathrm{h})$ & Santos et al. (2013) \\
\hline G. xylinus CGMCC 2955 & Defined & $\begin{array}{l}\text { Shake flasks } \\
\text { agitated }\end{array}$ & $\begin{array}{l}25 \mathrm{~g} / \mathrm{L} \mathrm{pGlyc}, 3 \mathrm{~g} / \mathrm{L} \\
\mathrm{Na} 2 \mathrm{HPO} 4,1 \mathrm{~g} / \mathrm{L} \\
\mathrm{KH} 2 \mathrm{PO} 4,5 \mathrm{~g} / \mathrm{L} \\
(\mathrm{NH} 4) 2 \mathrm{SO} 4,0.02 \mathrm{~g} / \mathrm{L} \\
\mathrm{MgCl} 2,0.02 \mathrm{~g} / \mathrm{LCaCl} 2 \\
0.0015 \mathrm{~g} / \mathrm{L} \text { paraamin- } \\
\text { obenzoic acid }\end{array}$ & $6.05 \mathrm{~g} / \mathrm{L}(0.050 \mathrm{~g} / \mathrm{L} / \mathrm{h})$ & Zhong et al. (2013) \\
\hline G. saccharisp. & HS & Static & $\begin{array}{l}20 \mathrm{~g} / \mathrm{L} \text { cGLYC, } 5 \mathrm{~g} / \mathrm{L} Y E \\
5 \mathrm{~g} / \mathrm{L} \text { Pep }\end{array}$ & $0.1 \mathrm{~g} / \mathrm{L}(0.1 \mathrm{mg} / \mathrm{L} / \mathrm{h})$ & Carreira et al. (2011) \\
\hline G. persimmonis GH-2 & HS & $\begin{array}{l}\text { Bioreactor } 5 \mathrm{~L}, \\
\text { agitated/aerated }\end{array}$ & $\begin{array}{l}20 \mathrm{~g} / \mathrm{L} \text { pGLYC, } 5 \mathrm{~g} / \mathrm{L} Y \mathrm{E}_{1} \\
5 \mathrm{~g} / \mathrm{L} \text { Pep }\end{array}$ & $2.47 \mathrm{~g} / \mathrm{L}(0.013 \mathrm{~g} / \mathrm{L} / \mathrm{h})$ & $\begin{array}{l}\text { Hungund and Gupta } \\
(2010 a)\end{array}$ \\
\hline $\begin{array}{l}\text { Enterobacter amnigenus } \\
\mathrm{GH}-1\end{array}$ & $\mathrm{HS}$ & Static & $\begin{array}{l}20 \mathrm{~g} / \mathrm{L} \text { pGLYC, } 5 \mathrm{~g} / \mathrm{L} Y \mathrm{E}_{1} \\
5 \mathrm{~g} / \mathrm{L} \text { Pep }\end{array}$ & $1.2 \mathrm{~g} / \mathrm{L}(0.004 \mathrm{~g} / \mathrm{L} / \mathrm{h})$ & $\begin{array}{l}\text { Hungund and Gupta } \\
(2010 b)\end{array}$ \\
\hline Acetobacter sp. V6 & $\begin{array}{l}\text { HS } \\
\text { modified }\end{array}$ & Shake flasks agitated & $\begin{array}{l}2 \% \mathrm{pGLYC}_{1} 1.6 \% \text { YE, } \\
0.4 \% \mathrm{Na}_{2} \mathrm{HPO} 4,0.35 \% \\
\text { succinic acid }\end{array}$ & $4.98 \mathrm{~g} / \mathrm{L}(0.030 \mathrm{~g} / \mathrm{L} / \mathrm{h})$ & Jung et al. (2010) \\
\hline G. xylinus ATCC 53,524 & $\mathrm{HS}$ & Static & $\begin{array}{l}20 \mathrm{~g} / \mathrm{L} \mathrm{pGLYC}, 5 \mathrm{~g} / \mathrm{L} \\
Y \mathrm{E}, 5 \mathrm{~g} / \mathrm{L} \text { Pep, } 2.7 \mathrm{~g} / \mathrm{L} \\
\mathrm{Na}_{2} \mathrm{HPO}_{4} \\
1.15 \mathrm{~g} / \mathrm{L} \text { citric acid }\end{array}$ & $3.75 \mathrm{~g} / \mathrm{L}(0.039 \mathrm{~g} / \mathrm{L} / \mathrm{h})$ & Mikkelsen et al. (2009) \\
\hline $\begin{array}{l}\text { Gluconacetobacter sp. } \\
\text { RKY5 }\end{array}$ & $\begin{array}{l}\text { HS } \\
\text { optimized }\end{array}$ & $\begin{array}{l}\text { Static } \\
\text { Shake flasks agitated }\end{array}$ & $\begin{array}{l}15 \mathrm{~g} / \mathrm{L} \text { pGLYC, } 8 \mathrm{~g} / \mathrm{L} Y E \\
3 \mathrm{~g} / \mathrm{LK}_{2} \mathrm{HPO}_{4}, 3 \mathrm{~g} / \mathrm{L} \mathrm{AA}\end{array}$ & $\begin{array}{l}4.59 \mathrm{~g} / \mathrm{L}(0.032 \mathrm{~g} / \mathrm{L} / \mathrm{h}) \\
5.63 \mathrm{~g} / \mathrm{L}(0.039 \mathrm{~g} / \mathrm{L} / \mathrm{h})\end{array}$ & Kim et al. (2006) \\
\hline G. xylinus ATCC 10,245 & $\mathrm{HS}$ & Static & $\begin{array}{l}10 \mathrm{~g} / \mathrm{L} \mathrm{pGLYC}, 5 \mathrm{~g} / \mathrm{L} \\
\mathrm{YE}, 5 \mathrm{~g} / \mathrm{L} \text { Pep, } 2.7 \mathrm{~g} / \mathrm{L} \\
\mathrm{Na}_{2} \mathrm{HPO}_{4}, 1.15 \mathrm{~g} / \mathrm{L} \text { citric } \\
\text { acid }\end{array}$ & & $\begin{array}{l}\text { Keshk and Shameshima } \\
(2005)\end{array}$ \\
\hline A. xylinum DA & YPD & Static & $\begin{array}{l}20 \mathrm{~g} / \mathrm{L} \mathrm{pGLYC,} 5 \mathrm{~g} / \mathrm{L} \\
\mathrm{YE}, 5 \mathrm{~g} / \mathrm{L} \text { Pep, } 2.7 \mathrm{~g} / \mathrm{L} \\
\mathrm{Na}_{2} \mathrm{HPO}_{4} \\
, 1.15 \mathrm{~g} / \mathrm{L} \text { citric acid, } \\
20 \mathrm{~g} / \mathrm{L} \mathrm{AA}\end{array}$ & $3.83 \mathrm{~g} / \mathrm{L}(0.016 \mathrm{~g} / \mathrm{L} / \mathrm{h})$ & Toda et al. (1997) \\
\hline A.xylinum IFO 13,693 & $\begin{array}{l}\text { HS } \\
\text { modified }\end{array}$ & Shake flasks agitated & $\begin{array}{l}0.5 \% \text { pGLYC,0.5\% YE, } 2 \% \\
\text { Pep,0.1\% } \mathrm{MgSO}_{4}, 0.2 \% \\
\text { Eth }\end{array}$ & $4.84 \mathrm{~g} / \mathrm{L}(0.067 \mathrm{~g} / \mathrm{L} / \mathrm{h})$ & Masaoka et al. (1993) \\
\hline
\end{tabular}

CMC carboxymethyl cellulose, $H S$ Hestrin-Schramm medium, YPD yeast extract-peptone-glucose medium, $A E$ acetate ethanol medium, $M A / 9$ unoptimized minimal medium, $p G L Y C$ pure glycerol, $c G L Y C$ crude glycerol, YE yeast extract, Pep peptone, Eth ethanol, $A A$ acetic acid, CSL corn steep liquor

${ }^{a} \mathrm{BC}$ concentration at the end of cultivation (specific productivity: increase in concentration on average per hour)

${ }^{b}$ Both expressed in wet weight

Dastager 2018; Soemphol et al. 2018) or modified (Jung et al. 2010; Volova et al. 2018; Li et al. 2019) Hestrin-Schramm (HS) medium commonly used for acetic acid bacteria, replacing conventional carbon sources (mono- or di-saccharides) with glycerol. In some cases, other nutrient media of defined (Al-Shamary and Al-Darwash 2013; Lu et al. 2020; Vigentini et al. 2019; Mangayil et al. 2021), semi-defined (Casarica et al. 2013) or complex (Vazquez et al. 2013) compositions were also employed. In a number of studies, a positive effect of increased glycerol concentrations on cellulose yield and specific productivity of the bioprocess as a whole was noted. Besides, the addition of various additives such as organic acids (Toda et al. 1997; Kim et al. 2006; Jung et al. 2010; Lins et al. 2019), ethanol (Masaoka et al. 1993; Volova et al. 2018; Lu et al. 2020), water-soluble polymers (Kose et al. 2013) to the culture medium can also significantly promote the formation of BC. By this time, purified glycerol is predominantly included in the composition of nutrient media, although a fairly high productivity for 
BC is also achieved when this source is used in a crude, i.e., not purified, form (Vazquez al. 2013; Gayathri and Srinikethan 2018; Yang et al. 2019; Lu et al. 2020). Quite comparable levels of $\mathrm{BC}$ yields are also shown for some producers when using both types of glycerol, which can be facilitated by the more appropriate composition of nitrogen sources (Lu et al. 2020). It should be noted that nutrient formulations currently use almost exclusively traditional nitrogen sources, such as yeast extract (YE) and/or peptone (Pep), although good potential has also been shown (Vazquez et al. 2013) for corn steep liquor (CSL). Replacing traditional nitrogen sources not only with the less expensive CSL, but also with other nitrogenrich extracts, concentrates and hydrolysates of natural origin is crucial for any further scaling of BC biosynthesis processes, as this would significantly reduce their overall costs. Such attempts using fish powder, soybean meal, malt extract, casein or fish hydrolysates in combination with glycerol have been performed with some success (Hungund and Gupta 2010b; Adnan 2015; Aswini et al. 2020). However, further in-depth studies of their optimal levels are required to maximize $\mathrm{BC}$ formation for different producers, at least commensurate with the productivity achieved by traditional sources. The situation is quite similar to the use of crude glycerol for the production of BC. It is well known that not purified glycerol contains a number of by-products (methanol, soap, inorganic salts, free fatty acid, unreacted acyl glycerols, etc.) whose composition and amounts are affected by possible differences in the biodiesel technologies used (Samul et al. 2013; Mangayil et al. 2021). Although crude glycerol (Wendisch et al. 2011; Posada et al. 2012), like purified glycerol (Kenar 2007; da Silva et al. 2009), is successfully used to obtain many value-added products, including $\mathrm{BC}$, by microbial conversion, such impurities can also adversely affect the activity of producer cells and the overall biosynthetic pathway. Such effects can be eliminated by some pre-treatment of crude glycerol, for which various partial or more complete purification methods have been developed (Posada et al. 2012; Yang et al. 2012). However, this can significantly increase the overall cost and should therefore be avoided. Thus, in order to ensure a high yield of $\mathrm{BC}$, which is undoubtedly achievable on a crude glycerol (Vazquez al. 2013; Gayathri and Srinikethan 2018; Yang et al. 2019; Lu et al. 2020), it is necessary to balance the physiological requirements of different producers for the substrate qualities with its composition at different origins through appropriate focused research for the accumulation and comparative analysis of more data (Samul et al. 2013). This would provide still absent, more general recommendations for the use of crude glycerol, thereby contributing to the cost efficiency of $\mathrm{BC}$ production. Compared with the mode of static cultivation (Table 1), BC production under aeration/agitation conditions has been studied much less frequently (Kim et al. 2006; Jung et al. 2010; Kose et al. 2013; Adnan et al. 2015), especially when using bioreactors (Hungund and Gupta 2010b; Adnan 2015). The yield and productivity achieved by BC are also quite moderate (Kim et al. 2006) not exceeding $5.63 \mathrm{~g} / \mathrm{L}(0.039 \mathrm{~g} / \mathrm{L} / \mathrm{h})$, thus lower compared to the several static cultivation data (Table 1). However, further research is needed in this direction, as it is well known that higher oxygen supply and volumetric agitation could promote increasing yields and specific productivity for producer strains, thus amplifying the bioprocess towards the large-scale industrial production

\section{Conclusions}

Glycerol as an undesirable and polluting by-product, i.e., waste generated in significant quantities in combination with biodiesel production requires greater re-use, including the production of valuable products through microbiological conversion.

This polyol, even in a crude unrefined form, can be used as a renewable carbon source for the production of $\mathrm{BC}$, which could stimulate the development of costefficient and environmentally friendly technologies to achieve an expanded use of this biopolymer within a broad and versatile range of practical applications. Since the data obtained so far remain somewhat one-sided and largely limited, the relevant research needs further development.

As with other carbon sources, the microbial synthesis of $\mathrm{BC}$ from glycerol is highly strain-dependent, that is, the yield, specific productivity and structural features of a biopolymer are determined by specific properties, both genotypic and phenotypic, of the producer. In turn, this creates the need for thorough studies and assessment of these properties, even for seemingly homogeneous strains for their appropriate full-fledged selection.

A much wider use of appropriate optimization techniques is required to identify and determine the optimal levels of the relevant factors for maximum $\mathrm{BC}$ formation by selected producers.

The inclusion of various nitrogen-rich extracts and hydrolysates of natural origin, which is still a rather rare, is particularly important in the development and optimization of cultivation media compositions, as this would significantly reduce the overall cost of BC synthesis.

There is a need to significantly expand the research on $\mathrm{BC}$ production from glycerol under aerated/agitated conditions, which are still noticeably less used than static cultivation, although they could promote increasing yields and specific productivity. However, the effect of such conditions should be additionally assessed in terms of their potential impact on the structural properties of 
$\mathrm{BC}$ and, consequently, on the suitability of the polymer for specific applications.

\section{Acknowledgements}

Not applicable.

\section{Authors' contributions}

General writing of the manuscript, investigation, data collection and analysis-PZ; data search, editing and design-SK and MR; conceptualization, critical revision and supervision-PS. All authors contributed to the study conception and design, read and approved the final manuscript. All authors read and approved the final manuscript.

\section{Funding}

This study was supported by the Ministry of Agriculture and Rural Support Service of the Republic of Latvia (Grant Number 19-00- A01612-000004).

\section{Availability of data and materials}

The datasets used and/or analyzed during the current study are available from the first author on reasonable request and/or are freely accessible via the Internet.

\section{Declarations}

Ethics approval and consent to participate

Not applicable.

\section{Consent for publication}

Not applicable.

\section{Competing interests}

The authors declare no competing interests.

Received: 22 August 2021 Accepted: 20 November 2021

Published online: 29 November 2021

\section{References}

Adeleye AT, Odoh CK, Enudi OC, Banjoko OO, Osigbeminiyi OO, Toluwalope OE, Louis H (2020) Sustainable synthesis and applications of polyhydroxyalkanoates (PHAs) from biomass. Process Biochem 96:174-193. https://doi.org/10.1016/j.procbio.2020.05.032

Adnan AB (2015) Production of Bacterial Cellulose Using Low-cost Media. Ph D Thesis. The University of Waikato

Adnan A, Nair GR, Lay MC, Swan JE, Umar R (2015) Glycerol as a cheaper carbon source in bacterial cellulose (BC) production by Gluconacetobacter xylinus DSM46604 in batch fermentation system. Malays J Anal Sci 19:1131-1136

Alemam AM, Shaheenb TI, El Din HS, Said E, Desoukya S, El-Gamala MS (2021) Production enhancement of bacterial cellulose nanofiber using local Komagataeibacter xylinus SB3.1 under static conditions. Egypt J Chem 64(4):2213-2221. https://doi.org/10.21608/EJCHEM.2021.52972.3096

Al-Shamary EE, Al-Darwash AK (2013) Influence of fermentation condition and alkali treatment on the porosity and thickness of bacterial cellulose membranes. Online J Sci Technol 3:194-203

Andriani D, Apriyana AY, Karina M (2020) The optimization of bacterial cellulose production and its applications: a review. Cellulose 27:6747-6766. https://doi.org/10.1007/s10570-020-03273-9

Arancon RD, Liu CSK, Chan KM, Kwan TH, Luque R (2013) Advances on waste valorization: new horizons for a more sustainable society. Energy Sci Eng 1(2):53-71. https://doi.org/10.1002/ese3.9

Aswini K, Gopal NO, Uthandi S (2020) Optimized culture conditions for bacterial cellulose production by Acetobacter senegalensis MA1. BMC Biotechnol 20(1):46. https://doi.org/10.1186/s12896-020-00639-6

Azeredo HMC, Barud H, Farinas CS, Vasconcellos VM, Claro AM (2019) Bacterial cellulose as a raw material for food and food packaging applications. Front Sustain Food Syst. https://doi.org/10.3389/fsufs.2019.00007
Azuma Y, Hosoyama A, Matsutani M, Furuya N, Horikawa H, Harada T, Hirakawa H, Kuhara S, Matsushita K, Fujita N, Shirai M (2009) Whole-genome analyses reveal genetic instability of Acetobacter pasteurianus. Nucleic Acids Res 37(17):768-5783. https://doi.org/10.1093/nar/gkp612

Bae S, Shoda M (2004) Bacterial cellulose production by fed-batch fermentation in molasses medium. Biotechnol Prog 20:1366-1371. https://doi. org/10.1021/bp0498490

Baptista AC, Ferreira IMM, Borges JPMR (2013) Cellulose-medical, pharmaceutical and electronic applications. In: Van De Ven T (ed) Cellulose-based bioelectronic devices. InTech, London, p 67

Barcelos MCS, Vespermann KAC, Pelissari FM, Molina G (2019) Current status of biotechnological production and applications of microbial exopolysaccharides. Crit Rev Food Sci Nutr 60:1475-1495. https://doi.org/10.1080/ 10408398.2019.1575791

Bettiga M, Hahn-Hägerdal B, Gorwa-Grauslund MF (2008) Comparing the xylose reductase/xylitol dehydrogenase and xylose isomerase pathways in arabinose and xylose fermenting Saccharomyces cerevisiae strains. Biotechnol Biofuels. https://doi.org/10.1186/1754-6834-1-16

Bianchet RT, Vieira Cubas AL, Machado MM, Siegel MEH (2020) Applicability of bacterial cellulose in cosmetics-bibliometric review. Biotechnol Rep. https://doi.org/10.1016/j.btre.2020.e00502

Blanco Parte FG, Santoso SP, Chou CC, Verma V, Wang HT, Ismadji S, Cheng KC (2020) Current progress on the production, modification, and applications of bacterial cellulose. Crit Rev Biotechnol 40:1-18. https://doi.org/ 10.1080/07388551.2020.1713721

Brown EE, Laborie MPG (2007) Bioengineering bacterial cellulose/ poly(ethylene oxide) nanocomposites. Biomacromol 8(10):3074-3081

Buldum G, Bismarck A, Mantalaris A (2018) Recombinant biosynthesis of bacterial cellulose in genetically modified Escherichia coli. Bioprocess Biosyst Eng 41:265-279. https://doi.org/10.1007/s00449-017-1864-1

Cacicedo ML, Castro MC, Servetas I et al (2016) Progress in bacterial cellulose matrices for biotechnological applications. Bioresour Technol 213:172-180. https://doi.org/10.1016/j.biortech.2016.02.071

Campano C, Ana Balea A, Blanco A, Negro C (2016) Enhancement of the fermentation process and properties of bacterial cellulose: a review. Cellulose 23(1):57-91. https://doi.org/10.1007/s10570-015-0802-0

Carreira P, Mendes JAS, Trovatti E, Serafim LS, Freire CSR, Silvestre AJD, Neto CP (2011) Utilization of residues from agro-forest industries in the production of high value bacterial cellulose. Bioresour Technol 102:7354-7360. https://doi.org/10.1016/j.biortech./2011.04.081

Casarica A, Campeanu G, Moscovici M, Ghiorghita A, Manea V (2013) Improvement of bacterial cellulose production by Acetobacter xylinum dsmz2004 on poor quality horticultural substrates using the taguchi method for media optimization. Part 1. Cell Chem Technol 47:61-68

Cazon P, Vázquez M (2021) Bacterial cellulose as a biodegradable food packaging material: a review. Food Hydrocoll 113(11):106530. https://doi.org/ 10.1016/j.foodhyd.2020.106530

Chao Y, Sugano Y, Shoda M (2001) Bacterial cellulose production under oxygen-enriched air at different fructose concentrations in a 50-liter, internal-loop airlift reactor. Appl Microbiol Biotechnol 55(6):673-679. https://doi.org/10.1007/s002530000503

Chawla PR, Bajaj IB, Survase SA, Singhal RS (2009) Microbial cellulose: fermentative production and applications. Food Technol Biotechnol 47(2):107-124

Cook J. (2013) Amine functionalization of bacterial cellulose for targeted delivery applications. Thesis. The University of Western Ontario

da Silva GP, Mack M, Contiero J (2009) Glycerol: a promising and abundant carbon source for industrial microbiology. Biotechnol Adv 27(1):30-39. https://doi.org/10.1016/j.biotechadv.2008.07.006

Dayal MS, Catchmark JM (2016) Mechanical and structural property analysis of bacterial cellulose composites. Carbohydr Polym 144:447-453. https:// doi.org/10.1016/j.carbpol.2016.02.055

de Oliveira Barud HG, da Silva RR, da Silva BH, Tercjak A, Gutierrez J, Lustri WR, de Oliveira Jr OB, Ribeiro SJL (2016) A multipurpose natural and renewable polymer in medical applications: Bacterial cellulose. Carbohydr Polym 153:406-420. https://doi.org/10.1016/j.carbpol.2016.07.059

Devi GK, Alamu A (2013) Production of biopolymer levan by Bacillus subtilis using non-ionic surfactants. Asian J Pharm Technol 3:149-154

Dikshit PK, Kim BS (2020) Bacterial cellulose production from biodiesel-derived crude glycerol, magnetic functionalization, and its application as carrier 
for lipase immobilization. Int J Biol Macromol. https://doi.org/10.1016/j. ijbiomac.2020.03.047

El-Malek FA, Khairy H, Farag A, Omar S (2020) The sustainability of microbial bioplastics, production and applications. Int J Biol Macromol 157(15):319-328. https://doi.org/10.1016/j.ijbiomac.2020.04.076

El-Saied H, El-Diwany Al, Basta AH, Atwa NA, El-Ghwas DE (2008) Production and characterization of economical bacterial cellulose. BioResources 3(4):1196-1217

Feldman D (2015) Cellulose nanocomposites. J Macromol Sci Part A 52(4):648658. https://doi.org/10.1080/10601325.2015.1007279

Freitas F, Alves VD, Reis MAM (2011) Advances in bacterial exopolysaccharides: from production to biotechnological applications. Trends Biotechnol 29(8):388-398. https://doi.org/10.1016/j.tibteh.2011.03.008

Fu L, Zhang J, Yang G (2013) Present status and applications of bacterial cellulose-based materials for skin tissue repair. Carbohydr Polym 92(2):1432-1442. https://doi.org/10.1016/j.carbpol.2012.10.071

Gahlawat G, Srivastava AK (2017) Model-based nutrient feeding strategies for the increased production of polyhydroxybutyrate (PHB) by Alcaligenes latus. Appl Biochem Biotechnol 83(2):530-542. https://doi.org/10.1007/ s12010-017-2482-8

Gayathri G, Srinikethan G (2018) Crude glycerol as a cost effective carbon source for the production of cellulose by $K$. saccharivorans. Biocatal Agric Biotechnol 16:326-330. https://doi.org/10.1016/j.bcab.2018.08. 024

Glenn K, Ingram-Smith C, Smith KS (2014) Biochemical and kinetic characterization of xylulose 5-phosphate/fructose 6-phosphate phosphoketolase 2 (Xfp2) from Cryptococcus neoformans. Eukaryot Cell 13(5):657-663. https://doi.org/10.1128/EC.00055-14

Gorgieva S, Trček J (2019) Bacterial cellulose: production, modification and perspectives in biomedical applications. Nanomaterials 9:1-20. https:// doi.org/10.3390/nano9101352

Gullo M, La China S, Falcone PM, Giudici P (2018) Biotechnological production of cellulose by acetic acid bacteria: current state and perspectives. Appl Microbiol Biotechnol 102(16):6885-6898. https://doi.org/10.1007/ s00253-018-9164-5

Gullo M, La China S, Petroni G, Di Gregorio S, Giudici P (2019) Exploring K2G30 genome: a high bacterial cellulose producing strain in glucose and mannitol based media. Front Microbiol 10:58. https://doi.org/10.3389/ fmicb.2019.00058

Huang Y, Zhu C, Yang J, Nie Y, Chen C, Sun D (2014) Recent advances in bacterial cellulose. Cellulose 21:1-30. https://doi.org/10.1007/ s10570-013-0088-z

Hungund BS, Gupta SG (2010a) Improved production of bacterial cellulose from Gluconacetobacter persimmonis GH-2. J Microbial Biochem Technol 2:127-133. https://doi.org/10.4172/1948-5948.1000037

Hungund B, Gupta SG (2010b) Production of bacterial cellulose from Enterobacter amnigenus $\mathrm{GH}-1$ isolated from rotten apple. World J Microbiol Biotechnol 26(10):1823-1828. https://doi.org/10.1007/ s11274-010-0363-1

Hussain Z, Sajjad W, Khan T, Wahid F (2019) Production of bacterial cellulose from industrial wastes: a review. Cellulose 26:2895-2911. https://doi. org/10.1007/s10570-019-02307-1

Hutchens SA, León RV, O'Neill HM, Evans BR (2007) Statistical analysis of optimal culture conditions for Gluconacetobacter hansenii cellulose production. Lett Appl Microbiol 44(2):175-180. https://doi.org/10.1111/j. 1472-765X.2006.02055.X

Ishida T, Mitarai M, Sugano Y, Shoda M (2003) Role of water-soluble polysaccharides in bacterial cellulose production. Biotechnol Bioeng 83(4):474-478. https://doi.org/10.1002/bit.10690

Jalili Tabaii M, Emtiazi G (2016) Comparison of bacterial cellulose production among different strains and fermented media. Appl Food Biotechnol 3(1):35-41. https://doi.org/10.22037/afb.v3i1.10582

Jang WD, Hwang JH, Kim HU, Ryu JY, Lee SY (2017) Bacterial cellulose as an example product for sustainable production and consumption. Microb Biotechnol 10:1181-1185. https://doi.org/10.1111/1751-7915.12744

Jozala AF, Pértile RAN, dos Santos CA, de Carvalho S-EV, Seckler MM, Gama FM, Pessoa A (2015) Bacterial cellulose production by Gluconacetobacter xylinus by employing alternative culture media. Appl Microbiol Biotechnol 99:1181-1190. https://doi.org/10.1007/s00253-014-6232-3

Jozala AF, de Lencastre-Novaes LC, Lopes AM, de Carvalho S-E, Mazzola PG, Pessoa A Jr, Grotto D, Gerenutti M, Chaud MV (2016) Bacterial nanocellulose production and application: a 10-year overview. Appl Microbiol Biotechnol 100(5):2063-2072. https://doi.org/10.1007/ s00253-015-7243-4

Jung HI, Jeong JH, Lee OM, Park GT, Kim KK, Park HC, Lee SM, Kim YG, Son HJ (2010) Influence of glycerol on production and structural-physical properties of cellulose from Acetobacter sp. V6 cultured in shake flasks. Bioresour Technol 101(10):3602-3608. https://doi.org/10.1016/j.biort ech.2009.12.111

Kenar JA (2007) Glycerol as a platform chemical: sweet opportunities on the horizon? Lipid Technol 19(11):249-253. https://doi.org/10.1002/lite. 200700079

Keshk S, Sameshima K (2005) Evaluation of different carbon sources for bacterial cellulose production. Afr J Biotechnol 4(6):478-482. https://doi.org/ 10.5897/AJB2005.000-3087

Kim J, Cai Z, Lee HS et al (2011) Preparation and characterization of a bacterial cellulose/chitosan composite for potential biomedical application. J Polym Res 18:739-744. https://doi.org/10.1007/s10965-010-9470-9

Kim SY, Kim JN, Wee YJ, Park DH, Ryu HW (2006) Production of bacterial cellulose by Gluconacetobacter sp. RKY5 isolated from persimmon vinegar. Appl Biochem Biotechnol 131(1-3):715-815. https://doi.org/10.1385/ ABAB:131:1:705

Klemm D, Schumann D, Kramer F, Heßler N, Hornung M, Schmauder HP, Marsch S (2006) Nanocelluloses as innovative polymers in research and application. In: Klemm D (ed) Polysaccharides II. Springer, Berlin

Kolesovs S, Semjonovs P (2020) Production of bacterial cellulose from wheycurrent state and prospects. Appl Microbiol Biotechnol 104(18):77237730. https://doi.org/10.1007/s00253-020-10803-9

Kose R, Sunagawa N, Yoshida M, Tajima K (2013) One-step production of nanofibrillated bacterial cellulose (NFBC) from waste glycerol using Gluconacetobacter intermedius NEDO-01. Cellulose 20:2971-2979. https:// doi.org/10.1007/s10570-013-0050-0

Kucera D, Pernicová I, Kovalcik A, Koller M, Mullerova L, Sedlacek P (2018) Characterization of the promising poly(3-hydroxybutyrate) producing halophilic bacterium Halomonas halophila. Bioresour Technol 256:552-556. https://doi.org/10.1016/j.biortech.2018.02.06

Kumar AS, Mody K, Jha B (2007) Bacterial exopolysaccharides-a perception. J Basic Microbiol 47(2):103-117. https://doi.org/10.1002/jobm.200610203

Kumar LR, Yellapu SK, Tyagi RD, Zhang X (2019) A review on variation in crude glycerol composition, bio-valorization of crude and purified glycerol as carbon source for lipid production. Bioresour Technol 293:122-155. https://doi.org/10.1016/j.biortech.2019.122155

La China S, Zanichelli G, De Vero L, Gullo M (2018) Oxidative fermentations and exopolysaccharides production by acetic acid bacteria: a mini review. Biotechnol Lett 40:1289-1302. https://doi.org/10.1007/ s10529-018-25917

Lappa IK, Papadaki A, Kachrimanidou V, Terpou A, Koulougliotis D, Eriotou E, Kopsahelis N (2019) Cheese whey processing: integrated biorefinery concepts and emerging food applications. Foods 8(8):347. https://doi. org/10.3390/foods 8080347

Laslo T, von Zaluskowski P, Gabris C, Lodd E, Rückert C, Dangel P, Kalinowski J, Auchter M, Seibold G, Eikmanns BJ (2012) Arabitol metabolism of Corynebacterium glutamicum and its regulation by AtIR. J Bacteriol 194(5):941-955 https://doi.org/101128/JB.06064-11

Lee S, Abraham A, Lim ACS, Choi O, Seo JG, Sang BI (2021) Characterisation of bacterial nanocellulose and nanostructured carbon produced from crude glycerol by Komagataeibacter sucrofermentans. Bioresour Technol 342:125918. https://doi.org/10.1016/j.biortech.2021.125918

Li J, Chen G, Zhang R et al (2019) Production of high crystallinity type-I cellulose from Komagataeibacter hansenii JR-02 isolated from Kombucha tea. Biotechnol Appl Biochem 66:108-118. https://doi.org/10.1002/bab. 1703

Li Z, Chen SQ, Cao X, Li L, Zhu J, Yu H (2021) Effect of pH buffer and carbon metabolism on the yield and mechanical properties of bacterial cellulose produced by Komagataeibacter hansenii ATCC 53582. J Microbiol Biotechnol 31(3):429-438. https://doi.org/10.4014/jmb.2010.10054

Licciardello F (2017) Packaging, blessing in disguise. Review on its diverse contribution to food sustainability. Trends Food Sci Technol 65:32-39. https://doi.org/10.1016/J.TIFS.2017.05.003

Lin AY, Nickerson TA (1977) Acid hydrolysis of lactose in whey versus aqueous solutions. J Dairy Sci 60(1):34-39 
Lins LSG, Silva WE, Belian MF, Calazans GMT (2019) Use of biodiesel waste for efficient production of cellulosic membranes A "green" proposal for filter preparation. Cellulose Chem Technol 53(5-6):417-425. https:// doi.org/10.35812/CelluloseChemTechnol.2019.553.42

Liu Y, Gu Q, Ofosu FK, Yu X (2015) Isolation and characterization of curdlan produced by Agrobacterium HX1126 using a-lactose as substrate. Int J Biol Macromol 81:498-503. https://doi.org/10.1016/j.ijbiomac.2015. 08.04

Lu T, Gao H, Liao B, Wu J, Zhang W, Huang J, Liu M, Huang J, Chang Z, Jin M, Yi Z, Jiang D (2020) Characterization and optimization of production of bacterial cellulose from strain CGMCC 17276 based on wholegenome analysis. Carbohydr Polym 232:115788. https://doi.org/10. 1016/j.carbpol.2019.115788

Lule VK, Singh R, Pophaly SD, Poonam SK, Tomar SK (2016) Production and structural characterisation of dextran from an indigenous strain of Leuconostoc mesenteroides BA08 in whey. Int J Dairy Tech 69(4):520531. https://doi.org/10.1111/1471-0307.12271

Lynch KM, Zannini E, Wilkinson S, Daenen L, Arendt EK (2019) Physiology of acetic acid bacteria and their role in vinegar and fermented beverages. Compr Rev Food Sci F 18(3):587-625. https://doi.org/10.1111/ $1541-4337.12440$

Mangayil R, Rissanen AJ, Pammo A, Guizelini D, Losoi P, Sarlin E, Tuukkanen S, Santala V (2021) Characterization of a novel bacterial cellulose producer for the production of eco-friendly piezoelectric-responsive films from a minimal medium containing waste carbon. Cellulose 28:671-689. https://doi.org/10.1007/s10570-020-03551-6

Marangoni C, Furigo A, De Aragão GMF (2002) Production of poly(3hydroxybutyrate-co-3-hydroxyvalerate) by Ralstonia eutropha in whey and inverted sugar with propionic acid feeding. Proc Biochem 38:137-141. https://doi.org/10.1016/j.biortech.2018.02.056

Masaoka S, Ohe T, Sakota N (1993) Production of cellulose from glucose by Acetobacter xylinum. J Ferment Bioeng 75(1):18-22

McNamara JT, Morgan JL, Zimmer J (2015) A molecular description of cellulose biosynthesis. Annu Rev Biochem 84:895-921. https://doi.org/ 10.1146/annurev-biochem-060614-033930

Mikkelsen D, Flanagan BM, Dykes GA, Gidley MJ (2009) Influence of different carbon sources on bacterial cellulose production by Gluconacetobacter xylinus strain ATCC 53524. J Appl Microbiol 107:576-583. https:// doi.org/10.1111/j.1365-2672.2009.04226.x

Millon LE, Wan WK (2006) The polyvinyl alcohol-bacterial cellulose system as a new nanocomposite for biomedical applications. J Biomed Mater Res B Appl Biomater 79(2):245-253. https://doi.org/10.1002/jbm.b. 30535

Minor FW, Greathouse GA, Shirk GA, Schwartz AM, Harris M (1954) Biosynthesis of C14-specifically labeled cellulose by Acetobacter xylinum. II. From D-mannitol-1-C14 with and without ethanol. J Am Chem Soc 76(20):5052-5054

Mohite BV, Koli SH, Narkhede CP, Patil SN (2017) Prospective of microbial exopolysaccharide for heavy metal exclusion. Appl Biochem Biotechnol 183:582-600. https://doi.org/10.1007/s12010-017-2591-4

Moniri M, Boroumand Moghaddam A, Azizi S, Abdul Rahim R, Bin Ariff A Zuhainis Saad W, Navaderi M, Mohamad R (2017) Production and status of bacterial cellulose in biomedical engineering. Nanomaterials (basel) 7(9):257. https://doi.org/10.3390/nano7090257

Morais E, Silva N, Sintra T, Santos SA, Neves B, Almeida I, Costa P, Correia-Sá I, Ventura SP, Silvestre A, Freire M, Freire C (2019) Anti-inflammatory and antioxidant nanostructured cellulose membranes loaded with phenolic-based ionic liquids for cutaneous application. Carbohydr Polym 206:187-197. https://doi.org/10.1016/j.carbpol.2018.10.051

Narancic T, O'Connor KE (2019) Plastic waste as a global challenge: are biodegradable plastics the answer to the plastic waste problem? Microbiology 165(2):129-137. https://doi.org/10.1099/mic.0.000749

Nguyen VT, Flanagan B, Gidley MJ, Dykes GA (2008) Characterization of cellulose production by a Gluconacetobacter xylinus strain from Kombucha. Curr Microbiol 57:449-453. https://doi.org/10.1007/s00284-008-9228-3

Nwodo U, Green E, Okoh A (2012) Bacterial exopolysaccharides: functionality and prospects. Int J Mol Sci 13(11):14002-14015. https://doi.org/10. 3390/ijms131114002

Oikawa T, Ohtori T, Ameyama M (1995a) Production of cellulose from D -Mannitol by Acetobacter xylinum KU-1. Biosci Biotechnol Biochem 59:331-332. https://doi.org/10.1271/bbb.59.331
Oikawa T, Morino T, Ameyama M (1995b) Production of cellulose from D-arabitol by Acetobacter xylinum KU-1. Biosci Biotechnol Biochem 59:1564-1565. https://doi.org/10.1271/bbb.59.1564

Oikawa T, Nakai J, Tsukagawa Y, Soda K (1997) A novel type of D-mannitol dehydrogenase from Acetobacter xylinum: occurrence, purification, and basic properties. Biosci Biotechnol Biochem 61:1778-1782. https://doi. org/10.1271/bbb.61.1778

Olivas GI, Barbosa-Cánovas GV (2005) Edible coatings for fresh-cut fruits. Crit Rev Food Sci Nutr 45(7-8):657-670. https://doi.org/10.1080/10408 690490911837

Onilude AA, Olaoye O, Fadahunsi IF, Owoseni A, Garuba EO, Atoyebi T (2013) Effects of cultural conditions on dextran production by Leuconostoc spp. Int Food Res J 20:1645-1651

Pacheco G, de Mello CV, Chiari-Andreo BG, Isaac VLB, Ribeiro SJL, Pecoraro E et al (2018) Bacterial cellulose skin masks-properties and sensory tests. J Cosmet Dermatol 17:840-847. https://doi.org/10.1111/jocd.12441

Park JK, Jung JY, Khan T (2009) Bacterial cellulose. In: Williams PA (ed) Phillips GO. Handbook of Hydrocolloids, Elsevier, pp 724-739

Park S, Baker JO, Himmel ME, Parilla PA, Johnson DK (2010) Cellulose crystallinity index: measurement techniques and their impact on interpreting cellulase performance. Biotechnol Biofuels 24:3-10. https://doi.org/10. 1186/1754-6834-3-10

Pathak H, Prasad A (2014) Applications and prospects of microbial polymers in textile industries. J Text Sci Eng 4:1000172. https://doi.org/10.4172/ 2165-8064.1000

Posada JA, Rincón LE, Carlos C, Cardona CA (2012) Design and analysis of biorefineries based on raw glycerol: Addressing the glycerol problem. Biores Technol 111:282-293. https://doi.org/10.1016/j.biortech.2012. 01.151

Raghavendran V, Asare E, Roy I (2020) Bacterial cellulose: biosynthesis, production, and applications. In: Poole RK (ed) Advances microbial physiology, vol 77. Elsevier, Oxford, pp 89-138. https://doi.org/10.1016/bs.ampbs. 2020.07.002

Raghunandan K, Kumar A, Kumar S, Permaul K, Singh S (2018) Production of gellan gum, an exopolysaccharide, from biodiesel-derived waste glycerol by Sphingomonas spp. 3 Biotech 8(1):71. https://doi.org/10 1007/s13205-018-1096-3

Ramana K, Tomar A, Singh L (2000) Effect of various carbon and nitrogen sources on cellulose synthesis by Acetobacter xylinum. World J Microbio Biotechnol 16:245-248. https://doi.org/10.1023/A:1008958014270

Ravindran R, Jaiswal AK (2016) Exploitation of food industry waste for highvalue products. Trends Biotechnol 34(1):58-69. https://doi.org/10. 1016/j.tibtech.2015.10.008

Rehm BHA (2010) Bacterial polymers: biosynthesis, modifications and applications. Nat Rev Microbiol 8:578-592. https://doi.org/10.1038/nrmic ro2354

Reiniati I, Hrymak AN, Margaritis A (2017) Recent developments in the production and applications of bacterial cellulose fibers and nanocrystals. Crit Rev Biotechnol 37:510-524. https://doi.org/10.1080/07388551.2016. 1189871

Römling U, Galperin MY (2015) Bacterial cellulose biosynthesis: diversity of operons, subunits, products, and functions. Trends Microbiol 23(9):545557. https://doi.org/10.1016/j.tim.2015.05.005

Rosa S, Lenz DM (2013) Biocomposites: Influence of matrix nature and additives on the properties and biodegradation behavior. In: Chamy R (ed) Biodegradation-engineering and technology. InTech, Rijeka

Sadh PK, Duhan S, Duhan JS (2018) Agro-industrial wastes and their utilization using solid state fermentation: a review. Bioresour Bioprocess 5:1-15. https://doi.org/10.1186/s40643-017-0187-z

Salari M, Sowti Khiabani M, Rezaei Mokarram R, Ghanbarzadeh B, Samadi Kafil H (2019) Preparation and characterization of cellulose nanocrystals from bacterial cellulose produced in sugar beet molasses and cheese whey media. Int J Biol Macromol 122:280-288. https://doi.org/10. 1016/j.ijbiomac.2018.10.136

Salihu R, Foong CY, Abd Razak SI, Kadir MRA, Yusof AHM, Nayan NHM (2019) Overview of inexpensive production routes of bacterial cellulose and its applications in biomedical engineering. Cell Chem Technol 53(1-2):113. https://doi.org/10.35812/CelluloseChemTechnol.2019.53.0133

Samul D, Leja K, Grajek W (2013) Impurities of crude glycerol and their effect on metabolite production. Ann Microbiol 64(3):891-898. https://doi. org/10.1007/s13213-013-0767-x 
Santos SM, Carbajo JM, Villar JC (2013) The effect of carbon and nitrogen sources on bacterial cellulose production and properties from Gluconacetobacter sucrofermentans CECT 7291 focused on its use in degraded paper restoration. BioResources 8:3630-3645. https://doi. org/10.15376/biores.8.3.3630-3645

Schilling Ch, Weiss S (2021) A roadmap for industry to harness biotechnology for a more circular economy. New Biotechnol 60(1):9-11. https:// doi.org/10.1016/j.nbt.2020.08.005

Semjonovs P, Ruklisha M, Paegle L, Saka M, Treimane R, Skute M, Rozenberga L, Vikele L, Sabovics M, Cleenwerck I (2017a) Cellulose synthesis by Komagataeibacter rhaeticus strain P 1463 isolated from Kombucha. Appl Microbiol Biotechnol 101:1003-1012. https://doi.org/10.1007/ s00253-016-7761-8

Semjonovs P, Shakirova L, Broks R, Kistkins S, Zikmanis P (2017b) Influence of environmental factors on extracellular fructan and oligosaccharide production by Gluconobacter nephelii. Res J Microbiol 12:33-41. https://doi.org/10.3923/jm.2017.33.41

Sen KY, Baidurah S (2021) Renewable biomass feedstocks for production of sustainable biodegradable polymer. Curr Opin Green Sustain Chem 27:1-6. https://doi.org/10.1016/j.cogsc.2020.100412

Shanmugam M, Abirami RG (2019) Microbial polysaccharides—chemistry and applications. J Bio Active Prod Nat 9:73-78. https://doi.org/10. 1080/22311866.2019.1571944

Shi Z, Zhang Y, Phillips GO, Yang G (2014) Utilization of bacterial cellulose in food. Food Hydrocoll 35:539-545. https://doi.org/10.1016/j.foodhyd. 2013.07.012

Singhsa P, Narain R, Manuspiya H (2018) Physical structure variations of bacterial cellulose produced by different Komagataeibacter xylinus strains and carbon sources in static and agitated conditions. Cellulose 25:1571-1581. https://doi.org/10.1007/s10570-018-1699-1

Siro I, Plackett D (2010) Microfibrillated cellulose and new nanocomposite materials - a review. Cellulose 17(3):459-494. https://doi.org/10 1007/s10570-010-9405-y

Sirohi R, Kumar Gaur V, Kumar Pandey A, Jun Sim S, Kumar S (2021) Harnessing fruit waste for poly-3-hydroxybutyrate production: a review. Bioresour Technol 326:124734. https://doi.org/10.1016/j.biortech. 2021.124734

Skvortsova ZN, Gromovykh TI, Gracheva VS, Traskina VY (2019) Physicochemical mechanics of bacterial cellulose. Colloid J 81:366-376 https://doi.org/10.1134/S1061933X19040161

Soemphol W, Hongsachart P, Tanamool V (2018) Production and characterization of bacterial cellulose produced from agricultural by-product by Gluconacetobacter strains. Mater Today Proc 5:11159-11168. https://doi.org/10.1016/j.matpr.2018.01.036

Son HJ, Heo MS, Kim YG, Lee SJ (2001) Optimization of fermentation conditions for the production of bacterial cellulose by a newly isolated Acetobacter sp. A9 in shaking cultures. Biotechnol Appl Biochem 33:1-5. https://doi.org/10.1042/BA20000065

Sperotto G, Stasiak LG, Godoi JP, Gabiatti NC, De Souza SS (2021) A review of culture media for bacterial cellulose production: complex, chemically defined and minimal media modulations. Cellulose 28:2649-2673. https://doi.org/10.1007/s10570-021-03754-5

Taban BM, Saichana N (2017) Physiology and biochemistry of acetic acid bacteria. In: Sengun IY (ed) Acetic acid bacteria: fundamentals and food applications. CRC Press, Boca Raton

Thoden JB, Holden HM (2007) Active site geometry of glucose-1-phosphate uridylyltransferase. Protein Sci 16(7):1379-1388. https://doi.org/10. 1110/ps.072864707

Thompson DN, Hamilton MA (2001) Production of bacterial cellulose from alternate feedstocks. Appl Biochem Biotechnol Part A Enzym Eng Biotechnol 91-93:503-513. https://doi.org/10.1385/ABAB:91

Thorat MN, Dastager SG (2018) High yield production of cellulose by a Komagataeibacter rhaeticus PG2 strain isolated from pomegranate as a new host. RSC Adv 8:29797-29805. https://doi.org/10.1039/C8RA0 $5295 \mathrm{~F}$

Tiwari ON, Sasmal S, Kataria AK, Devi I (2020) Application of microbial extracellular carbohydrate polymeric substances in food and allied industries. 3 Biotech 10:221. https://doi.org/10.1007/s13205-020-02200-w

Toda K, Asakura T, Fukaya M, Entani E, Kawamura Y (1997) Cellulose production by acetic acid-resistant Acetobacter xylinum. J Ferment Bioeng 84(3):228-231. https://doi.org/10.1016/s0922-338x(97)82059-4
Tonouchi N (2016) Cellulose and other capsular polysaccharides of acetic acid bacteria. In: Matsushita K, Toyama H, Tonouchi N, Okamoto-Kainuma A (eds) Acetic acid bacteria: ecology and physiology. Springer, Tokyo

Torres DPM, Gonçalves MPF, Teixeira JA, Rodrigues LR (2010) Galacto-oligosaccharides: production, properties, applications, and significance as prebiotics. Compreh Rev Food Sci Food Saf 9(5):438-454. https://doi. org/10.1111/j.1541-4337.2010.00119.x

Trindade RA, Munhoz AP, Burkert CAV (2015) Raw glycerol as an alternative carbon source for cultivation of exopolysaccharide-producing bacteria. Appl Biotechnol 3:61-73

Trovatti E, Serafim LS, Freire CSR, Silvestre AJD, Neto CP (2011) Gluconacetobacter sacchari: an efficient bacterial cellulose cell-factory. Carbohydr Polym 86:1417-1420. https://doi.org/10.1016/j.carbpol.2011.06.046

Tsang YF, Kumar V, Samadar P, Yang Y, Lee J, Ok YS, Song H, Kim KH, Kwon EE, Jeon YJ (2019) Production of bioplastic through food waste valorization. Environ Int 127:625-644. https://doi.org/10.1016/j.envint.2019.03.076

Tsouko E, Kourmentza C, Ladakis D, Kopsahelis N, Mandala I, Papanikolaou S, Paloukis F, Alves V, Koutinas A (2015) Bacterial cellulose production from industrial waste and by-product streams. Int J Mol Sci 16:14832-14849. https://doi.org/10.3390/ijms160714832

UI-Islam M, Khan S, Ullah MW, Park JK (2015) Bacterial cellulose composites: synthetic strategies and multiple applications in biomedical and electro-conductive fields. Biotechnol J 10:1847-1861. https://doi.org/ 10.1002/biot.201500106

Ul-Islam M, Ullah MJ, Khan S, Shah N, Park JK (2017) Strategies for cost-effective and enhanced production of bacterial cellulose. Int J Biol Macromol 102:1166-1173. https://doi.org/10.1016/j.ijbiomac.2017.04.110

UI-Islam M, Ullah MW, Khan S, Park JK (2020) Production of bacterial cellulose from alternative cheap and waste resources: a step for cost reduction with positive environmental aspects. Korean J Chem Eng 37:925-937. https://doi.org/10.1007/s11814-020-0524-33

Ummartyotin S, Sain M (2016) Cellulose composites for electronic devices. Nova Science Publishers Inc, New York

Vazquez A, Foresti ML, Cerrutti P, Galvagno M (2013) Bacterial cellulose from simple and low cost production media by Gluconacetobacter xylinus. $J$ Polym Environ 21:545-554. https://doi.org/10.1007/s10924-012-0541-3

Velasco-Bedrán H, López-Isunza F (2007) The unified metabolism of Gluconacetobacter entanii in continuous and batch processes. Process Biochem 42(8):1180-1190

Vigentini I, Fabrizio V, Dellacà F, Rossi S, Azario I, Mondin C, Benaglia M, Foschino R (2019) Set-up of bacterial cellulose production from the genus Komagataeibacter and its use in a gluten-free bakery product as a case study. Front Microbiol 10:1953. https://doi.org/10.3389/fmicb.2019. 01953

Volova TG, Prudnikova SV, Sukovatyi AG, Shishatskaya El (2018) Production and properties of bacterial cellulose by the strain Komagataeibacter xylinus B-12068. Appl Microbiol Biotechnol 102:7417-7428. https://doi.org/10. 1007/s00253-018-9198-8

Wang S-S, Han Y-H, Chen J-L et al (2018) Insights into bacterial cellulose biosynthesis from different carbon sources and the associated biochemical transformation pathways in Komagataeibacter sp W1. Polymers (basel) 10:963. https://doi.org/10.3390/polym10090963

Wendisch VF, Meiswinkel T, Lindner S (2011) Use of glycerol in biotechnological applications. In: Montero G, Stoytcheva M (eds) Biodiesel—quality emissions and by-products. InTech, Rijeka

Wu M, Chen W, Hu J, Tian D, Shen F, Zeng Y, Yang G, Zhang Y, Deng S (2019) Valorizing kitchen waste through bacterial cellulose production towards a more sustainable biorefinery. Sci Total Environ 695:133898. https://doi.org/10.1016/j.scitotenv.2019.133898

Yang F, Hanna MA, Sun R (2012) Value-added uses for crude glycerol_-a byproduct of biodiesel production. Biotechnol Biofuels 5:13. https://doi. org/10.1186/1754-6843-5-13

Yang HJ, Lee T, Kim JR, Choi Y-E, Park Ch (2019) Improved production of bacterial cellulose from waste glycerol through investigation of inhibitory effects of crude glycerol-derived compounds by Gluconacetobacter xylinus. J Ind Eng Chem 75:158-163. https://doi.org/10.1016/j.jiec.2019. 03.017

Yasuda K, Gong JP, Katsuyama Y, Nakayama A, Takanabe Y, Kondo E, Ueno M, Osada Y (2005) Biomechanical properties of high-toughness double network hydrogels. Biomaterials 26:4468-447510. https://doi.org/10. 1016/j.biomaterials.2004.11.021 
Zhong C (2020) Industrial-scale production and applications of bacterial cellulose. Front Bioeng Biotechnol 8:605374. https://doi.org/10.3389/fbioe. 2020.60537.4

Zhong C, Zhang GC, Liu M, Zheng XT, Han PP, Jia SR (2013) Metabolic flux analysis of Gluconacetobacter xylinus for bacterial cellulose production. Appl Microbiol Biotechnol 97:6189-6199. https://doi.org/10.1007/ s00253-013-4908-8

Zikmanis P, Kolesovs S, Semjonovs P (2020a) Production of biodegradable microbial polymers from whey. Bioresour Bioprocess 7:36. https://doi. org/10.1186/s40643-020-00326-6
Zikmanis P, Brants K, Kolesovs S, Semjonovs P (2020b) Xtracellular polysaccharides produced by bacteria of the Leuconostoc genus. World J Microbiol Biotechnol 36(11):161. https://doi.org/10.1007/s11274-020-02937-9

\section{Publisher's Note}

Springer Nature remains neutral with regard to jurisdictional claims in published maps and institutional affiliations.

\section{Submit your manuscript to a SpringerOpen ${ }^{\circ}$ journal and benefit from:}

- Convenient online submission

- Rigorous peer review

- Open access: articles freely available online

- High visibility within the field

- Retaining the copyright to your article

Submit your next manuscript at $\boldsymbol{\nabla}$ springeropen.com 